\title{
Obituary
}

\section{Edward Hughesdon Davis $1920-1981$}

Professor E. H. Davis died suddenly at his home in Sydney, Australia on 26 February 1981, and his untimely death has deprived the geotechnical community in Australia of one of its most eminent members.

Ted Davis was born in London in 1920 and obtained a degree with first class honours at University College, University of London. He then worked as an Assistant Fngineer with $\mathrm{Sir}$ Alexander Gibb and Partners and with Dr Oscar Faber on Ordnance Factory construction. In 1942 he joined the Royal Engineers and served as a lieutenant in the UK and Italy. At the end of the war he remained in the occupation forces in Italy and attained the rank of major in the Army Education Corps before being demobilized in 1947 .

During the next three years he began on what was to be his life's work in the study of soil mechanics as a Senior Scientific Officer at the Road Research Laboratory. His academic career opened when he was appointed a lecturer at his old college in 1950. In 1952 he went to Sydney University as a Senior Lecturer in Civil Engineering and began to develop lectures and laboratory classes in soil mechanics for undergraduate students. Those early days at Sydney were certainly not easy as there were few staff, many students and very limited facilities, but Davis was not deterred from his objective of putting on a sound theoretical basis a subject which had hitherto been largely empirical. He perceived that progress and understanding would only come

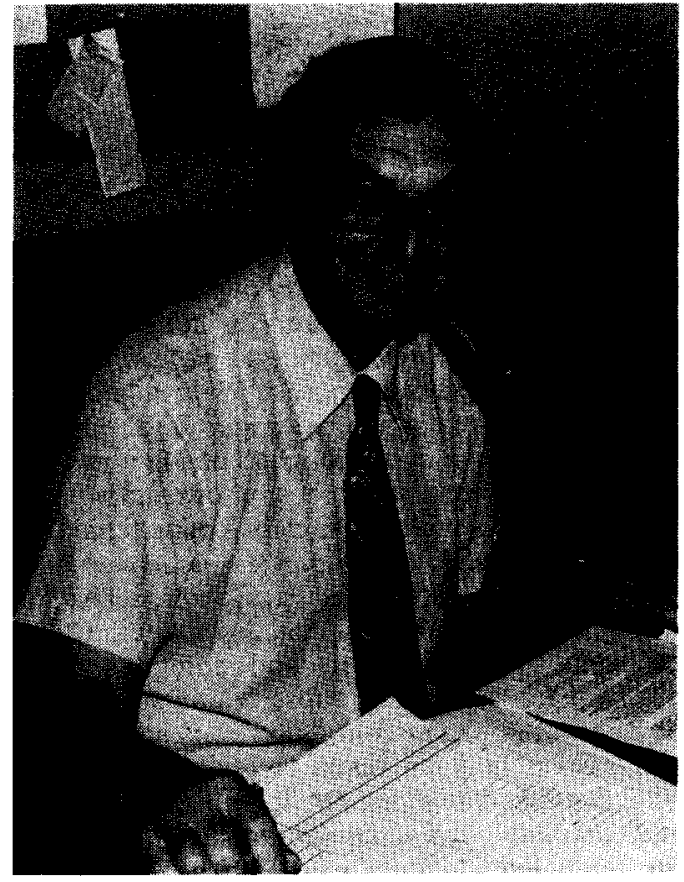

if a consistent, theoretically sound, albeit simplified, model of soil behaviour were used as a starting point. Accordingly, he began to develop and apply the theory of elasticity to foundation deformation problems, and the theory of plasticity to soil stability problems. These two topics remained the major research interests in his career and both were advanced significantly by his work. His use of elastic theory for settlement prediction, though received with initial scepticism by some, formed the basis of a unified method of settlement analysis of pads, piles and raft foundations which is now widely used in practice. However, his acceptance of elastic theory as a basis for settlement analysis did not mean that he was unaware of the potential shortcomings of this simple model as a representation of real soil. He continually emphasized the need to use elastic theory with due caution and with parameters which were determined over an appropriate stress range. His philosophy was therefore similar to that of Professor Lambe of MIT who was, at about the same time, developing the stresspath method of deformation analysis.

Professor Davis was also deeply interested in the problem of the rate of settlement prediction. He continually sought to improve the theory of consolidation and moved away from a consideration of the simple one-dimensional case to obtain important fundamental solutions to problems in two and three dimensions. He was quick to realize the importance of incorporating non-linear effects 
and produced several significant and elegant solutions.

While studying problems involving the stability of soil masses, Davis became convinced that further progress in this area would only be possible if a more rigorous approach, based on the theory of plasticity, were adopted. He grappled with the problem of applying the theory of plasticity to the assessment of soil stability and to the problem of understanding the relevance and significance of traditional engineering approaches in relation to the more rigorous theory. In doing so, he developed an understanding of the subject second to none. $\mathrm{He}$ applied limit theorems to cohesive soils and investigated their validity for other classes of material. $\mathrm{He}$ recognized the shortcomings of the associated flow rule model and developed a tractable model with a non-associated flow rule. A wide variety of problems was considered and solutions were obtained for the bearing capacity and stability of homogeneous and non-homogeneous soil masses and slopes. In later years, he and his research students linked together the theories of elasticity and plasticity and consolidation and explored the complete load-deformation behaviour of foundations. One of his major interests at the time of his death was the accurate prediction of collapse loads for foundations and soil masses using both load path and bounding techniques.

Davis was always extremely conscious of the link between theory and practice, the relationship between the idealized and the real material and the engineering significance of his research. He was reluctant to publish the results of research before its implications had been fully explored and understood and, consequently, some of his work, particularly in relation to plasticity theory, has not yet appeared. Nevertheless, he authored or coauthored three books, three chapters in books, and 55 technical papers.

His influence extended outside the boundaries of Australia. He spent three periods of study leave in the UK and the United States and left an indelible impression at the Massachussetts Institute of Technology, Cambridge University and the University of Swansea, among others.

One of Davis's greatest attributes was his ability to stimulate and encourage his research students and colleagues. He encouraged students to undertake broad areas of research and not to confine their attention to a small aspect of a problem and, in so doing, helped then gain a broad appreciation of the subject. He was never too busy to view the latest findings of an enthusiastic research student or colleague and would willingly put aside his administrative chores to discuss and critically appraise the proffered results. His ability to detect flaws in logical or theoretical arguments saved his colleagues and students from embarrassment on more than one occasion.

Within Sydney University he was appointed Associate Professor of Soil Mechanics in 1963 and Professor of Civil Engineering (Soil Mechanics) in 1968. He was head of the Department of Civil Engineering from 1979 until his death and undertook the many administrative tasks this position demanded with sensitivity and quiet diplomacy. Outside the University he was active in professional affairs and helped establish the Australian Geomechanics Society in 1970. Ten years earlier, he had been the major force in establishing the Sydney Soil Mechanics Group, which met on a quite informal basis to discuss matters of practical and theoretical interest. $\mathrm{He}$ was active in the Australian Geomechanics Society until his death, and had served as the Australasian Vice-President of the International Society of Soil Mechanics and Foundation Engineering for the period 1969-73.

While he will probably be best remembered as an academic, Davis's insistence on the need for a sound analytical basis was accompanied by a recognition of the practical significance of the work he was developing. As a result, his advice was widely sought on a variety of major projects and foundation problems around Australia.

His colleagues and friends were delighted when in $\mathbf{1 9 8 0}$ he was honoured in two ways for his work in theoretical soil mechanics. He was elected a Fellow of the Australian Academy of Science and was awarded the inaugural John Jaeger Memorial Medal by the Australian Geomechanics Society. At the Third Australian-New Zealand Geomechanics Conference in Wellington, New Zealand, at which the Medal was awarded, he delivered what was to be his final major lecture on the subject of plasticity solutions relevant to the bearing capacity of rock and fissured clay. This lecture described some of his recent work which he felt bridged the gap between soil and rock mechanics and was enthusiastically received. With characteristic modesty, Ted publically attributed his award to the co-operative efforts of his research group.

Despite his many university, professional and consulting commitments, he was first and foremost a family man. In earlier days, he took great delight, with his charming wife Kitty, in taking their children Andrew, Catherine and James on camping trips, and more recently, with the children grown, Ted and Kitty had explored much of the Australian countryside. The Davis family were fine hosts, and enjoyed entertaining visitors from overseas and showing them the beauties of their adopted home city of Sydney.

Ted Davis will be remembered as a kind and civilized man, concerned for his family and his students, as a distinguished practitioner and contri- 
butor to the art and science of geomechanics, but above all, as one who insisted on the highest standards of intellectual rigour in the academic study of engineering subjects. His many colleagues and students who have learned from him provide a continuing memorial to his work.

$$
\text { J. R. B., H. G. P. }
$$

\section{BIBLIOGRAPHY}

Road research notes (Crowthorne: Transport and Road Research Laboratory)

1948 An investigation of the plate-bearing strength of soft ground for large penetrations. RN/940.

1948 The measurement of the strength properties of soils with particular reference to pavement design. RN/1051.

1948 The construction of an experimental road to compare the performance of different types of base and bituminous surfacing. RN/1372.

1949 An investigation of the defects in roads on the Isle of Wight using three methods of pavement design. RN/1089.

1949 An investigation into the subsoil conditions within the Port of London Dock Estate at Tilbury, and proposals for an experimental road. RN/1216.

1949 An investigation into the causes of cracking of some of the concrete slabs forming an experimental length of Thornbury by-pass. RN/1219.

1949 Proposalsfor the construction of an experimental road to study the performance of different types of base and bituminous surface. RN/1121.

1949 The measurement of soil strength. RN/1246.

$1950 \mathrm{~A}$ review of pavement design from the soil mechanics standpoint. RN/978.

Papers

1949 The California Bearing Ratio method for the design of flexible roads and runaways. Géotechnique 1, No. 4, 249-263.

1952 A review of methods of pavement design. Road research technical paper no. 20. London: HMSO.

1953 A theory of the undrained strength of partially saturated non-dilated soils. Proceedings of conference on soil science, Adelaide.

1954 The estimation of changes in soil strength subsequent to construction of airfield pavements. Proceedings of symposium on soil stabilization, Dept. of Supply (Australia).

$1956 \mathrm{~A}$ general theory of the undrained strength of soils and its application to stability analysis. Proc, 2nd Australia-New Zealand Conf. Soil Mech.

$1960 \mathrm{An}$ investigation for an iron ore storage area. Proc. 3rd Australia-New Zealand Conf. Soil Mech.

1961 The surface displacement of an elastic layer due to horizontal and vertical surface loading. Co-author: $\mathbf{H}$. Taylor. Proc. 5th Int. Conf. Soil Mech.

1962 The movement of bridge approaches and abutments on soft foundation soils. Co-author: $H$. Taylor. Proceedings of 1 st biennial conference Australian Road Research Board.

1963 Triaxial testing and three-dimensional settlement analysis. Co-author: H. G. Poulos. Proc. 4th Australia-New Zealand Conf. Soil Mech.

1964 The movement of buried footings due to movement and horizontal load and the movement of anchor plates. Co-author. D. J. Douglas. Géotechnique 14, No. 2, 115-132.

1965 The analysis of settlement under three-dimensional conditions. Co-author: H. G. Poulos. Proceedings of symposium on soft ground engineering, Brisbane.

1965 A non-linear theory of consolidation. Co-author: $\mathbf{G}$. P. Raymond. Géotechnique 15, No. 2, 161-173.

1966 Laboratory investigations of the effects of sampling. Proceedings of symposium on site investigation, Sydney. Co-author. H. G. Poulos. Published in Civ. Engng Trans. Instn Engrs, Aust., April, 1967.

1967 A discussion of theories of plasticity and limit analysis in relation to the failure of soil masses. Proc. 5th Australia-New Zealand Conf. Soil Mech.

1968 The use of elastic theory for settlement prediction under three-dimensional conditions. Co-author: H. G. Poulos. Géotechnique 18, No. 1, 67-91.

1968 The settlement behaviour of single axially-loaded incompressible piles and piers. Co-author: H. G. Poulos. Géotechnique 18, No. 3, 351-371.

1969 One-dimensional consolidation of layered soils. Co-author: I. K. Lee. Proc. 7th Int. Conf. Soil Mech.

1969 A summary of some recent solutions for the theoretical behaviour of piles. Co-author. H. G. Poulos. Proc. 7th Int. Conf. Soil Mech., Specialty Session No. 8.

1970 First road base experiment with a laboratory test track. Co-author: G. H. Sparks. Proceedings of 5th Australian Road Research Board conference.

1971 Anisotropic cohesive strength and bearing capacity. Co-author. J. T. Christian. J. Soil Mech. Fdns Div., Am. Soc. Civ. Engrs.

1971 Consolidation at constant rate of strain. Coauthors: A. Wissa, J. T. Christian and S. Heiberg. J. Soil Mech. Fdns Div., Am. Soc. Civ. Engrs.

1971 The bearing capacity of strip footings from the standpoint of plasticity theory. Co-author: J. R. Booker. Proc. lst Australia-New Zealand Geomech. Conf.

1971 Non-linear consolidation and the effect of layer depth. Proc. Ist Australia-New Zealand Geomech. Conf.

1971 A study of the settlement characteristics of the soil deposits at Kingsford-Smith Airport. Co-authors: I. K. Lee, B. R. Rodway and R. Mallam. Austr. Geomech. $J$.

1972 The development of negative friction with time in end-bearing piles. Co-author: H. G. Poulos Austr. Geomech. $J$.

1972 The analysis of pile-raft systems. Co-author: H. G. Poulos. Austr. Geomech. J.

1972 A general treatment of plastic anisotropy under conditions of plane strain. Co-author: J. R. Booker. J. Mech. Phys. Solids.

1972 Rate of settlement under three-dimensional conditions. Co-author. H. G. Poulos. Géotechnique 22, No. 1, 95-114.

1972 Laboratory determination of in situ horizontal stresses in soil masses. Co-author: H. G. Poulos. Géotechnique 22, No. 1, 177-182.

1972 A note on the plasticity solution to the stability of slopes in inhomogeneous clay. Co-author: J. R. Booker. Géotechnique 22, No. 3, 509-513. 
1972 Estimation of the settlement of cross-anisotropic deposits using isotropic theory. Co-authors: C. M. Gerrard and L. J. Wardle. Austr. Geomech. J.

1973 Theory of piles in swelling and shrinking soils. Coauthor: H. G. Poulos. Proc. 8th Int. Conf. Soil Mech., Moscow.

1973 Some adaptations of classical plasticity to soil mechanics. Co-author: J. R. Booker. Proceedings of symposium on the role of plasticity in soil mechanics, Cambridge.

1973 The effect of increasing strength with depth on the bearing capacity of clays. Co-author. J. R. Booker. Géotechnique 23, No. 4, 551-563.

1974 The significance of the rate of plastic work in clastoplastic analysis. Co-authors: G. J. Ring and J. R. Booker. Proceedings of conference on finite element methods in engineering, Sydney.

1974 Buckling of finite beams in elastic continuum. Coauthor: M. R. Madhav. J. Appl. Mech. Div., Am. Soc. Civ. Engrs, Dec.

1975 Prediction of downdrag forces in end-bearing piles. Co-author: H. G. Poulos. J. Geotech. Engng Div., Am. Soc. Civ. Engrs, Feb.

1975 Application of plasticity theory to foundations. Co-author: J. R. Booker. Proceedings of symposium on soil mechanics-recent developments, University of New South Wales.

1975 Predicted and measured behaviour of an embankment on Boston blue clay. Co-author: H. G. Poulos. Austr. Geomech. J. G5, No. 1.

1976 Elasto-plastic consolidation of soil. Co-authors: J. C. Small and J. R. Booker. Int. J. Solids Struct.

1976 Methods of calculating long-term creep settlements. Co-authors: H. G. Poulos and L. P. de Ambrosis. $J$.
Geotech. Engng Div., Am. Soc. Civ. Engrs, July, GT7.

1976 Elasto-plastic consolidation of soils. Co-authors: J. C. Small and J. R. Booker. Int. J. Solids Struct. 12, 431-488.

1977 Finite deformation of an elastoplastic soil. Coauthors: J. P. Carter and J. R. Booker. Int. J. Num. Meth. Geomech. 1, April.

1980 The relief of negative skin friction on piles by electro-osmosis. Co-author: H. G. Poulos. Proc. 3rd Australia-New Zealand Conf. Geomech., Wellington,

1980 Some plasticity solutions relevant to the bearing capacity of rock and fissured clay. Proc. 3rd Australia-New Zealand Conf. Geomech., Wellington.

1980 The stability of shallow tunnels and underground openings in cohesive material. Co-authors: M. J. Gunn, R. J. Mair and H. N. Seneviratne. Géotechnique 30, No. 4, 397-416.

\section{Books}

1952 Soil mechanics for road engineers. London: HMSO. Chapters on 'Pavement design' and 'Measurement of soil strength'.

1968 Soil mechanics-selected topics. London: Butterworths. Chapter on 'Theories of plasticity and the failure of soil masses'.

1974 Elastic solutions for soil and rock mechanics. Coauthor: H. G. Poulos. New York: J. Wiley.

1977 Numerical methods in geotechnical engineering. New York: McGraw-Hill. Chapter on 'Stability analysis by plasticity theory'. Co-author: J. R. Booker.

1979 The profession of a civil engineer. Co-author: D. Campbell-Allen. Sydney: Sydney University Press.

1980 Pile foundation analysis and design. Co-author: $\mathrm{H}$. G. Poulos. New York: J. Wiley. 